Eur. J. Mineral.

1992, 4, 581-595

\title{
Origin of Eocene-covered karst bauxites of the Transdanubian Central Range (Hungary) : evidence for early Eocene volcanism
}

\author{
ISTVÁN DUNKL \\ Hungarian Academy of Sciences, Laboratory for Geochemical Research, \\ H-1112, Budapest, Budaörsi út 45, Hungary
}

\begin{abstract}
Fission track (FT) ages measured in detrital zircon crystals from Eocene-covered bauxites of the Transdanubian Central Range (TCR) appear to reflect the cooling age of the source rock(s). Thus, by means of FT-dating of zircons new information could be obtained to explain the problem of source rocks debated so far. Since the majority of the detrital zircon crystals proved to be euhedral, their typologic analysis permitted conclusions regarding the petrographic character of the source rocks as well.

(1) In the light of the age results it is clear that the pyroclastics of a Pre-Middle Eocene volcanism contributed to the bauxite material which was deposited on the exposed karstified carbonate terrain. Andesitic tuffite layers intercalated in the upper part of the overlying Eocene sequence are traces of younger explosions of the same Paleogene volcanic event. Zircon grains found in the bauxite are morphometrically identical to those found in the younger Eocene pyroclastics of andesitic character.

(2) A euhedral zircon population of 210 to 260 million years was also identified in some of the bauxite deposits studied. These crystals derive most probably from Middle Triassic trachyandesite tuffs of the Central Range, though anatectic granitic sources cannot be excluded.

(3) Those zircon grains which are the oldest and fairly well rounded are thought to derive from the parametamorphic of Hercynian age of the surrounding areas.

The bauxites of the TCR, though obviously of polygenetic origin, clearly received considerable amounts of pyroclasic contribution related to a Lower Eocene to Lower Lutetian volcanic event and this probably played an important role in the formation of the deposits.
\end{abstract}

Key-words : bauxite, zircon typology, fission track dating, Eocene volcanism, Hungary.

\section{Introduction}

FT-dating of detrital zircon grains of bauxites is a new approach to throw light on the source rocks of bauxites. Geological evidence shows that in the Transdanubian Central Range bauxite apparently were never subjected to any significant thermal effect, which would have resulted in the rejuvenation of fission track (FT) ages of zircon grains (their depth of burial is insignificant, no volcanic or hydrothermal influence could be proved). Therefore, the FT age of each individual detrital zircon grain in the bauxite records the cooling/formation age of part of the source rocks. In addition to this, typologic analysis (Pupin, 1976) of euhedral zircon grains may provide new data regarding the composition and genesis of the suspected source rocks.

\section{Genetic review of bauxites of the Transdanubian Central Range}

Bauxite occurs at three stratigraphic horizons in the Transdanubian Central Range (Dudich \& Komlóssy, 1969) : 1) horizon with Albian cover, 2) 

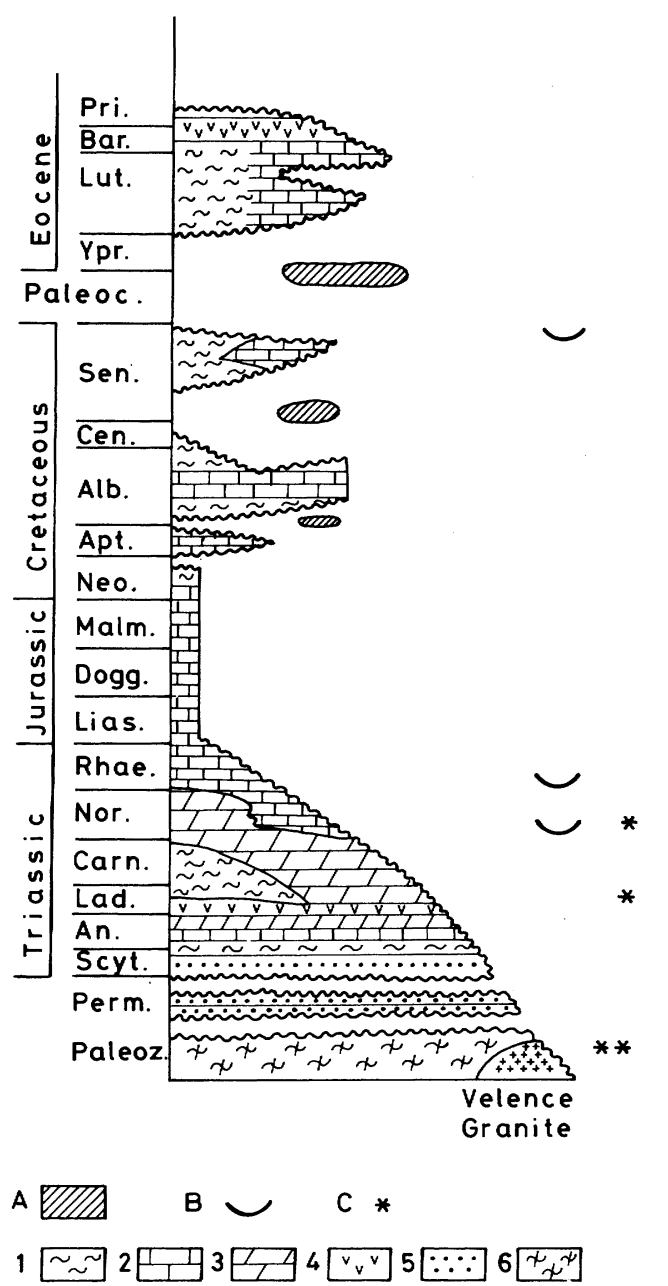

Fig. 1. Stratigraphic column of the Transdanubian Central Range (after Knauer, in Szantner et al., 1986).

A : Bauxite complex.

B : Footwall of the Eocene-covered deposits.

C : Presumed source rocks of bauxites.
$1:$ marl
4 : volcanic tuff
$2:$ limestone
5 : sandstone
3 : dolomite
$6:$ metamorphite

horizon with Senonian cover and 3) horizon with Eocene cover (Fig. 1). In the present work, only samples derived from the Eocene-covered Csabpuszta Bauxite (Mindszenty et al., 1988) were studied.

According to the latest paleogeographical reconstruction (Kázmér, 1984) the Bakony Unit presently lies east of that position which it oc-

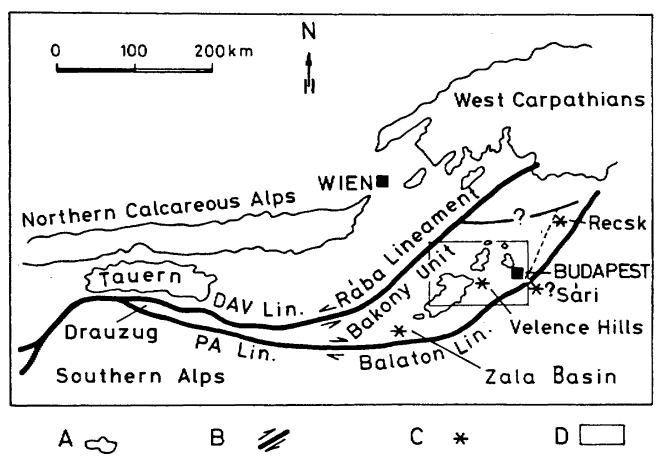

Fig. 2. Structural position of the Bakony unit in the Alp-Carpathian system (compilation based on maps of Kázmér, 1984 and Balla, 1988).

A : Distribution of some characteristic Paleo-Mesozoic formations

B : Transcurrent fault zone.

C : Paleogene volcanic centres.

D : Investigated area, see Fig. 3.

PA : Periadritatic Lineament

DAV Lin. : Defereggental-Anterselva-Valles Lineament

cupied at the time of Cretaceous-Eocene bauxite formation. This means that potential source rocks should not be looked for in areas now lying beyond the transcurrent fault lines bordering the Bakony Unit from the SE and NW (Fig. 2). Lack of factual information regarding details of the paleogeography have inhibited the establishment of the provenance of the " pre-bauxitic " material, and this resulted in various, partly contradicting theories on bauxite genesis.

Different theories on bauxite formation were suggested by Bárdossy (1961, 1977), Szabó (1976) and Dudich (1981). The essence of these theories can be briefly summarized as follows :

- Telegdi-Roth (1927) and Vadász (1946, 1951, 1956) related the emplacement of lateritic weathering products to the karstic surface and subsequent bauxitization. Transportation was supposed to have been of eolian type by György (1923).

- According to the " terra rossa " theory the karst bauxites were formed from the argillaceous dissolution residua of the calcareous bed rocks, essentially " in situ » with negligible transportation (Földvári, 1933 ; De Weisse, 1948 ; Komlóssy, 1967, 1970 ; Vendel et al., 1971 ; Hidasi, 1986).

- Pávai Vajna (1948) believed bauxites to have been of hydrothermal origin. 
- Gedeon (1952) considered the bauxite an alteration product of volcanic tuffs under shallowmarine conditions.

- Boldizsár (1948), Kiss \& Vörös (1965) as well as Nemecz \& Varjú (1967) derived bauxite by precipitation from a colloidal system in a lacustrine environment.

The question of the source material of bauxites has been debated for a long time. The investigation of detrital minerals provides the most direct information but geochemical, textural and paleogeographic analyses may also be relevant in this respect. It is worthy of mention that the abundance of heavy minerals in the Eocenecovered bauxites shows an upward increase (Vörös, 1958), as does the number of the heavy mineral species present. The most common detrital minerals recognized are as follows :

- Ilmenite, ferri-ilmenite (abundance : generally 70 to $90 \%$ of the 60 to 200 micrometer fraction, with the exception of the Southern Bakony occurrences where its proportion may be considerably smaller than that, see Mindszenty, 1970),
- zircon (Vörös, 1958 ; Antal, 1973 and TGecse, 1982, reported euhedral, acicular and rounded zircon populations of various color and shape),

- chromite (Kiss, 1952, 1955 ; Jaskó, 1953),

- metamorphic heavy minerals : tourmaline, rutile, corundum, garnet, staurolite, kyanite (Mindszenty et al., 1986/87 ; Mindszenty \& GálSolymos, 1988).

Biotite, weathered feldspar and dihexagonal quartz have also been reported in smaller amounts only (Vörös, 1958 ; Szabó \& Ravasz, 1970).

The difference between the heavy mineral content and extraclasts of the Eocene- and the Senonian-covered bauxites probably reflects the remarkable paleogeographic change which tookplace during Paleocene-Lower Eocene times. The transport of fine metamorphic detritus onto the karstic surface apparently began after the burial of the Cretaceous bauxites. At the same time an " ilmenite-supplying event " occurred as a result of either the erosion of igneous rocks or of volcanism (Mindszenty et al., 1988).
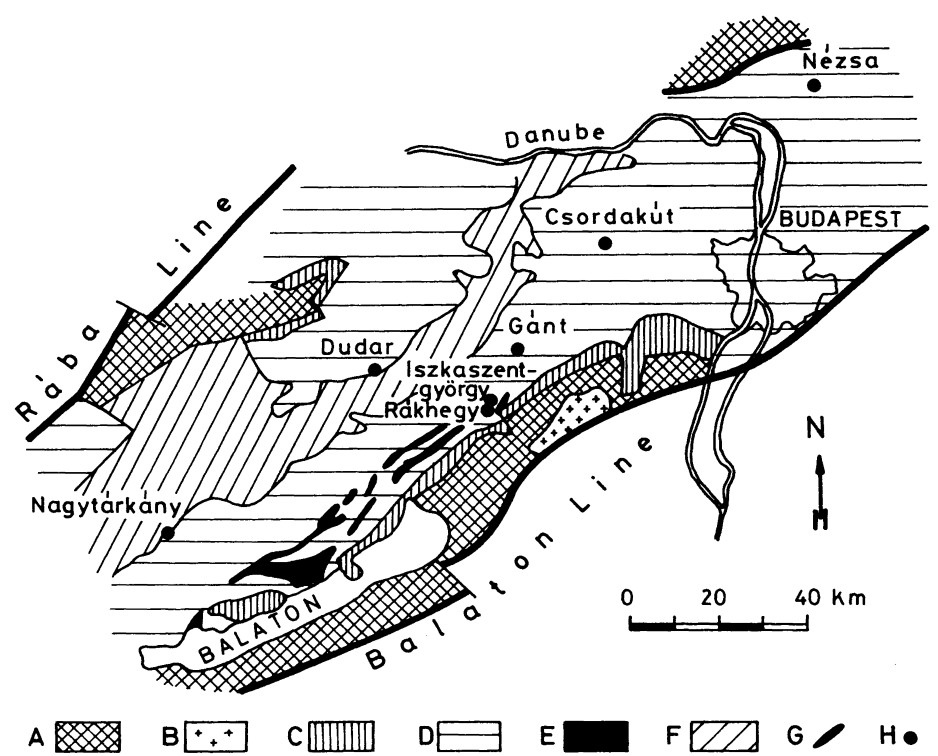

Fig. 3. Geological sketch map of the Transdanubian Central Range without Cenozoic formations (after Mindszenty, 1984 ; Fülöp \& Dank, 1987 with simplifications).
A : Paleozoic crystalline basement.
B : Velence granite.
C : Permian clastic strata.
D : Triassic, mostly carbonate formations.
E : Tuffaceous Middle Triassic strata.
F : Jurassic-Cretaceous strata.
$\mathrm{G}$ : Bordering transcurrent fault zone.
$\mathrm{H}$ : Bauxite deposits studied. 
In the southeastern margin of the Transdanubian Central Range, the metamorphics outcropping below the Mesozoic carbonate sequence were considered as source rocks by Bárdossy (1961) and Oravecz (1965), see Fig. 3. The granite of the Velence Hills also belongs to this strip. Based on the similarities of the composition of the detrital monazite and xenotime grains from the bauxites and of the accessory minerals in the granite, Bárdossy \& Pantó (1973), Bárdossy et al. (1976) and Pantó (1980), suggested that bauxite was derived from the acid magmatites of the Velence Hills.

The Ladinian trachytic tuffs intercalated within the partly eroded Triassic sequence of the Bakony Mountains were also believed to have been source rocks for the bauxites (Szabó \& Ravasz, 1970).

Most of the authors agree that bauxites are of mixed origin : both the Mesozoic sequences and the Paleozoic rocks to the south contributed to the formation of the deposits (Barnabás, 1966 ; Szabó, 1976 ; Vörös \& T. Gecse, 1978 ; Bárdossy, 1977).

The age of bauxites in the Transdanubian Central Range is uncertain due to the considerable stratigraphic gap between the underlying Triassic and Cretaceous and the overlying Eocene strata (Vadász, 1946 and Szantner et al., 1986), see Fig. 1.

Paleogeographic-tectonic considerations and paleoclimatic factors are important to the age of formation. According to Dudich \& Komlóssy (1969), the Eocene-covered deposits were formed during the Paleocene-Lower Eocene bauxite formation horizon, whereas Szantner \& Szabó (1970) claimed that formation of the Gánt, Iszkaszentgyörgy and Fenyöfö deposits took place between Cretaceous and Eocene.

Between the Triassic and the Eocene there were only a few periods when the climatic conditions permitted the formation of bauxite (Góczán, 1973). The latest suitable climatic period lasted from the Upper Paleocene to the Middle Eocene.

When trying to establish the age of deposition of any given bauxite horizon, the upper boundary is conventionally taken as the age of immediate cover ; in this case that of the overlying Eocene sediments. The age of the cover sequence is Lutetian ; NP 14 zone in the southern Bakony Mountains ; northeastwards the NP 16/17 zone becomes predominant (Báldi-Beke, 1984 ; Bignot et al., 1985).
To determine directly the age of deposition of bauxites, fossils occurring in the deposits may serve as a guide. However, generally karst bauxites are very poor in fossils (Bárdossy, 1977) and very rarely contain " index » fossils. In the Eocene-covered bauxite deposits of the Transdanubian Central Range Eocene palynomorphs, foraminifers, mannoplankton, sporomorphs, unidentified microforms and fern sporangia were described ; unfortunately, all of them unsuitable for age determinations (e.g. Deák, 1960, 1967 ; Antal, 1973 ; Báldi-Beke, 1974, 1984 ; Rákosi, 1977 ; Brokés, 1976 ; Kiss, 1953). Foraminifers relate only to redeposition in the Eocene and according to Deák (1960) Eocene pollen in the bauxite deposits are the results of secondary infiltration from the overlying Eocene sequence. According to Báldi-Beke (1974, 1984), however, Lower Lutetian nannoplankton forms were emplaced into the deposits during the accumulation of bauxite and therefore they do reflect the age of the deposits.

\section{Analytical methods}

Samples were taken from the following mining sites : Csordakút, Gánt-Harasztos, Gánt-Ujfeltárás, Iszkaszentgyörgy, Rákhegy, Dudar, Nagytárkány and Nézsa (Fig. 3). In the heavy mineral concentrates zircon proved to be the only mineral suitable for fission track dating. Except for the somewhat anomalous Nézsa samples its quantity was rather small : from 200 to $1200 \mathrm{~g}$ of bauxite 22 to 105 grains of suitable size zircon crystals could be separated.

Experimental techniques are described in the appendix. Due to the expected heterogeneity of the age of the individual grains, in the first step, fission track data were graphically evaluated. To distinguish the populations of different ages and to evaluate the results, three kinds of diagrams were used :

1) «Isochron diagram » : it displays the spontaneous and induced track densities measured in the crystals. The slope of the straight lines drawn from the origin to the measured data expresses the age (Fig. 4).

2) The " rake diagram " displays the individual measurements together with the error bars in increasing order. It is especially suitable to distinguish the populations by means of this diagram ; the cluster consisting of measurements of different reliability can easily be evaluated (Fig. 4). 

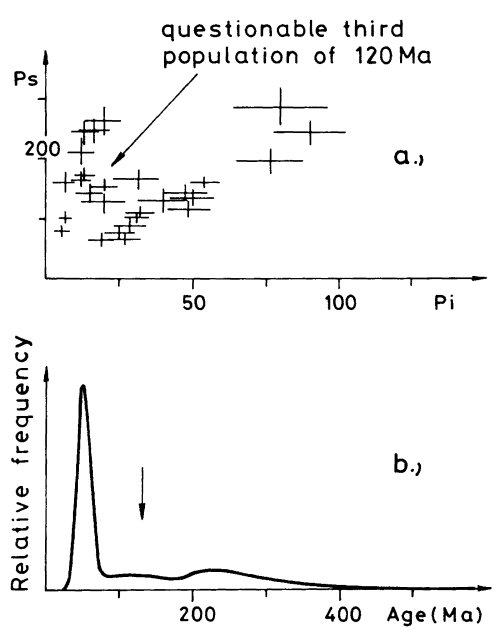

Fig. 4. Segregation of a younger and an older crystal population in a bauxite sample from Gánt (C-7).

a). Isochron diagram.

$\left.\begin{array}{l}\mathrm{Ps}: \text { spontaneous } \\ \mathrm{Pi} \text { : induced }\end{array}\right\}$ track density, $10^{5} \mathrm{tracks} / \mathrm{cm}^{2}$

b). « Rake diagram. "

3) " Age spectrum ». This is an evaluation method applied to FT ages measured on detrital mineral populations by Hurford et al. (1984). A Gaussian distribution curve corresponding to the reliability of data is fitted to the measurements and then the Gaussian curves are integrated. According to the authors, in the case of mixed populations, the maxima of the resultant curves denote the values characteristic of each group (Fig. 5).

Using these diagrams the zircon populations were grouped and the ages were computed on the basis of the weighted average of the track densities measured in the grains.

Typologic classification according to Pupin (1976) was carried out on idiomorphic crystals. This method is based on the determination of the ratio of prism and pyramid faces under the microscope (Fig. 6). Typological classes of accessory zircon crystals can be fairly well correlated with granitoids of different genesis (Pupin, 1980). To use the method quantitatively and with a reasonable reliability, the evaluation of at last one hundred crystals is usually needed. Since the case of our bauxite samples this number of crystals was for the most part not available, the results should be considered as " informative " only, and the " centers " calculated from the percentage ratio of crystals falling into the individual cells of the diagram (IT and IA values) serve also for qualitative information only.
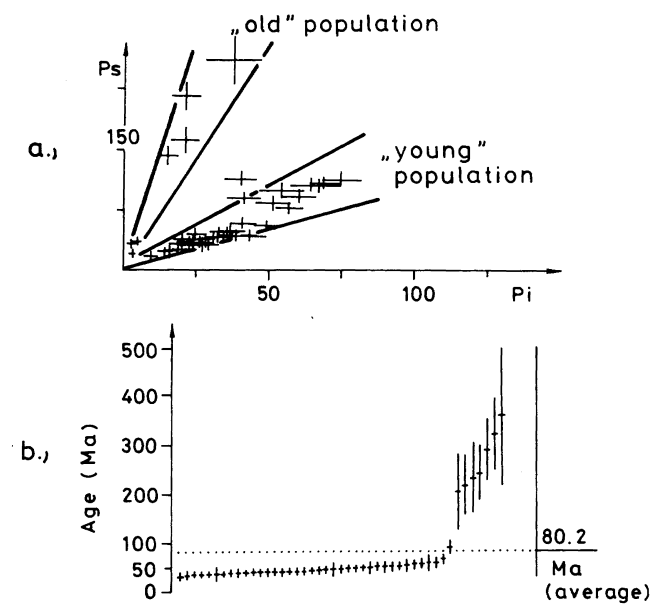

Fig. 5. Probably independent crystal population between the two main groups of results in Rákhegy, (C-51) sample. The segregation is represented in two ways : isochron diagram (a), age spectra (b).

\section{Fission track results}

1) In almost all specimens the majority of the zircon crystals formed a rather young population of quite uniform age. In some of the specimens, older grains were also found and these always clustered around one or two points in the age-diagram though their distribution was never as definite as that of the younger population (Table 1).

2) In samples derived from different bauxite deposits with Eocene cover, the age of the younger populations shows a very narrow range, i.e. it falls always between 40 and 50 million years.

3) Ages measured in older crystals show much greater dispersion, though some of the data points generally fall in the range of $200-260$ million years.

4) In the Nézsa samples only the younger grain assemblage could be identified. Their FT age is markedly younger than that of all the other bauxites of the Transdanubian Central Range.

5) As shown by Fig. 7., the majority of the Eocene-covered specimens (localities Csordakút, Gánt, Iszkaszentgyörgy and Rákhegy) provided zircon crystals whose ages fall into an extremely narrow range, proving the homogenity and therefore the common origin of the populations.

6) In the case of the Dudar and Nagytárkány the younger maxima of the age spectrum is asymmetric. It means that they also contain some 


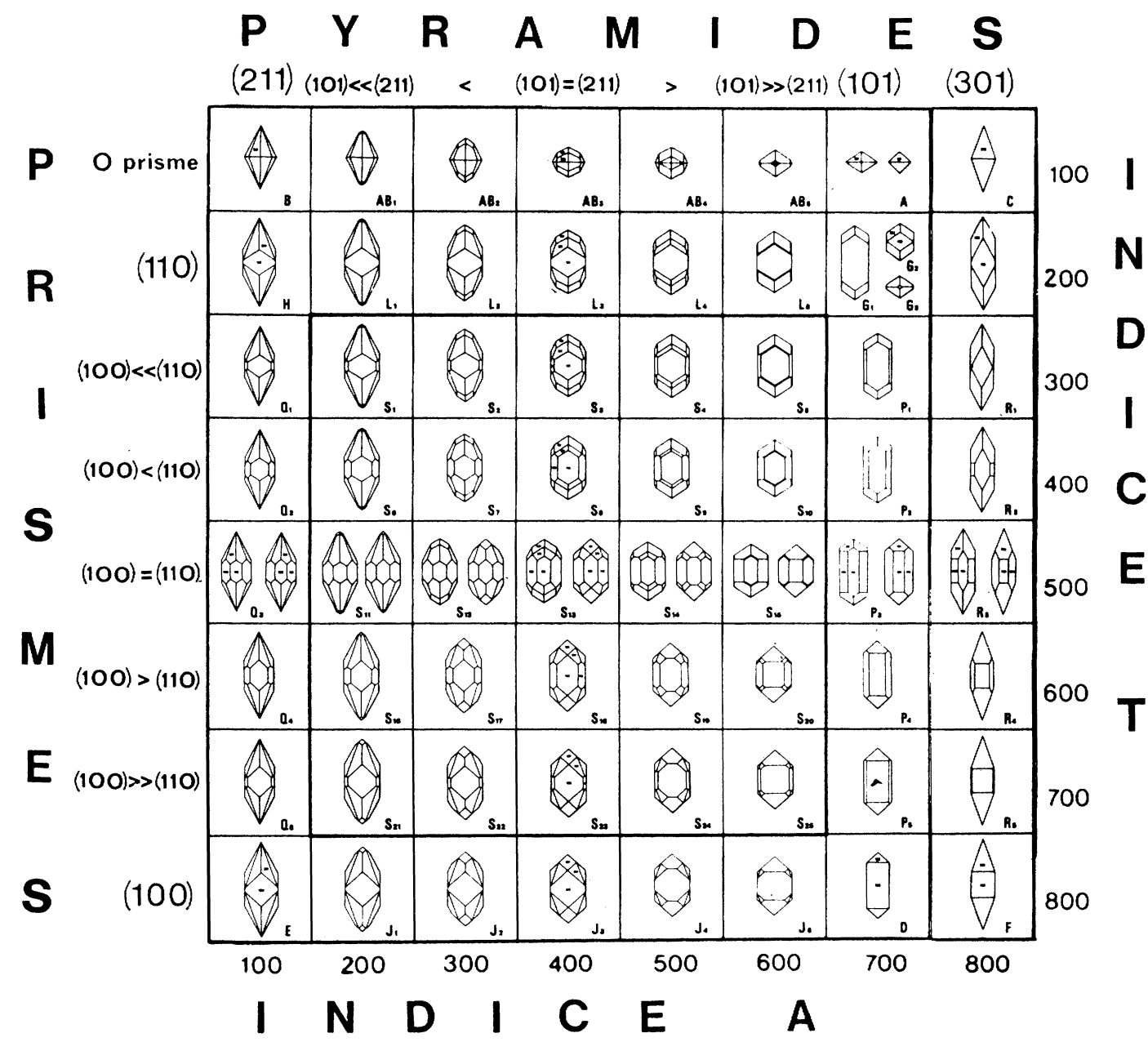

Fig. 6. The typologic classification of zircon crystals (Pupin, 1976).

grains which are only slightly older than the main, " young " population. The distinction between these two is impossible.

\section{Typological classification of the zircon crystals}

The crystal morphology of the detrital zircon grains proved to be rather similar in each of the studied bauxites. In some of the samples zircons were always characterized by a particular combination of crystal forms and in the' samples also the age spectrum was homogeneous. The results of the fission track method and the morphometry correlate fairly well and suggest that of these zircon crystals are of monomictic origin. In other samples where the shape of the euhedral crystals showed either greater variation or was of double maximum, the age spectra also proved to be complex (Fig. 7).

The majority of the detrital zircons measured fall into fields S-7, S-12 (Fig. 6 and 7). According to Pupin this is the area characteristic of diorites - quartz diorites - tonalites. In the samples of Gánt, Rákhegy and Nagytárkány ; another maximum, i.e. field S-23-24-25 could also be distinguished. This is the field for calcalkalic granodiorites - monzogranites (Pupin, 1980). He noted that among the non-granitic rocks the crystals of this type can also be found in trachyandesites and calc-alkaline rhyolites. 
Table 1. Fission track age of detrital zircon grains of bauxites of Transdanubian Central Range

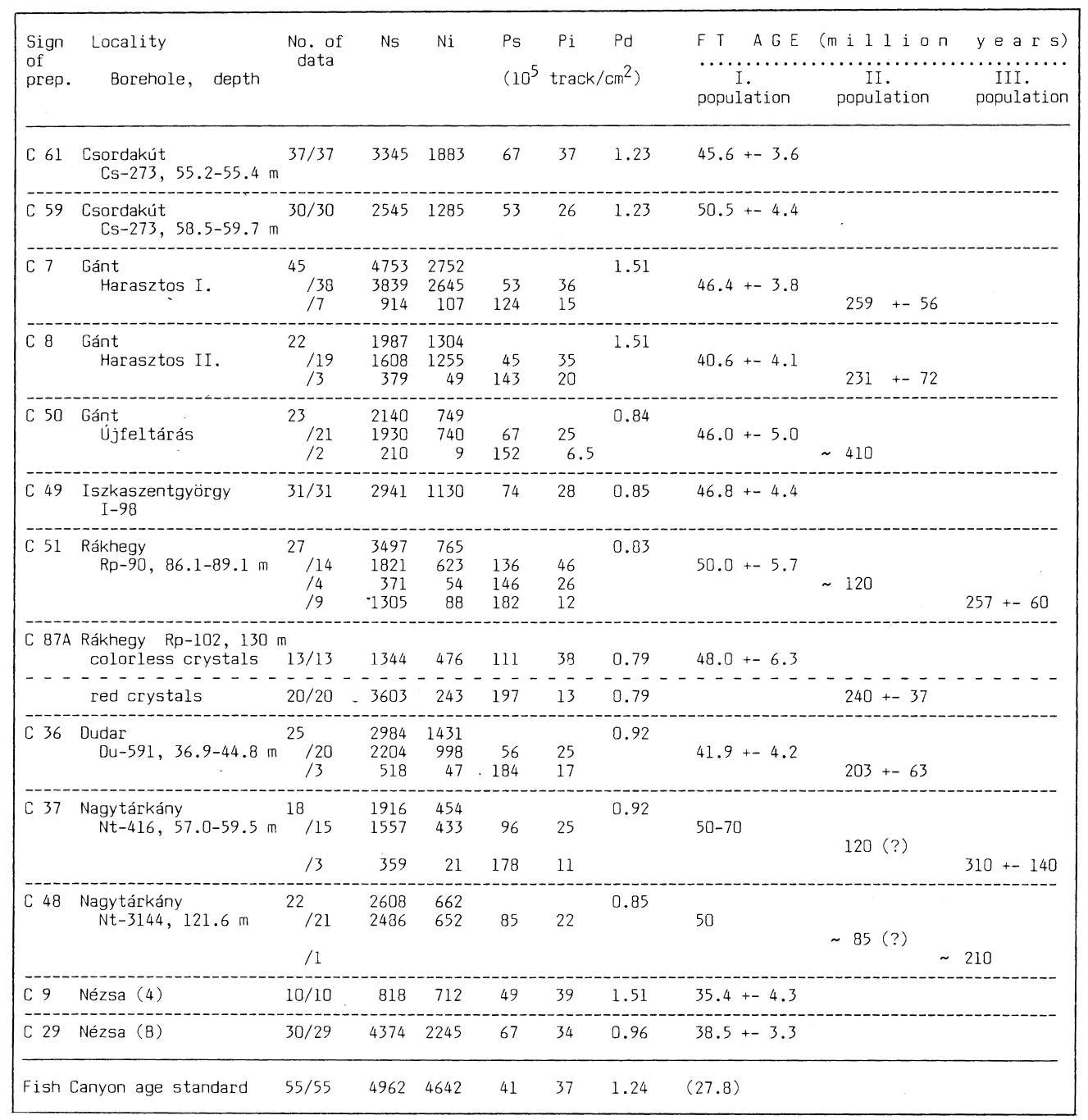

No. of data : Number of investigated crystals.

$/$ : Number of crystals in sundered populations.

(Number of tracks are in same division.)

$\mathrm{Ns}, \mathrm{Ni}$ : Number of spontaneous and induced tracks.

$\mathrm{Ps}, \mathrm{Pi}$ : Density of spontaneous and induced tracks $\left(10^{5} \mathrm{track} / \mathrm{cm}^{2}\right)$.

$\mathrm{Pd}$ : Density of induced tracks on NBS 962a standard glass $\left(10^{5} \mathrm{track} / \mathrm{cm}^{2}\right)$.

Zircon zeta for NBS 962 determined by Fish Canyon age standard : 415 .

\section{Geological interpretation}

A) The majority of the zircon crystals in the studied bauxites are of pyroclastic origin from a common volcanic source because :
- the crystals are completely intact (unrounded/unworn),

— the color of the crystals is always the same ; by typology they fall within a narrow range,

- the FT age of the crystals falls into a very 


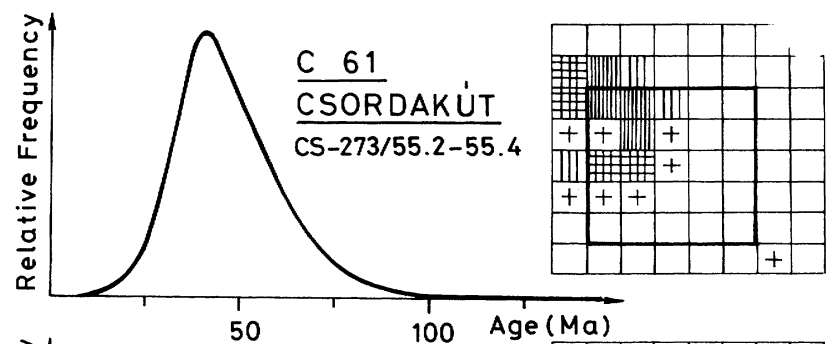

1. A. $=223$

I. $T=339$

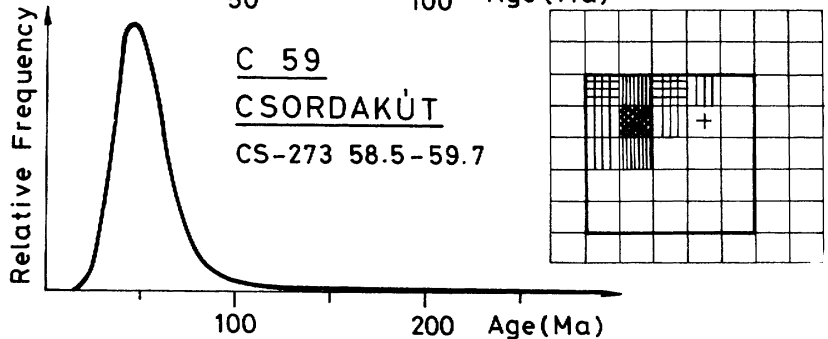

1. A. $=306$

I. T. $=382$

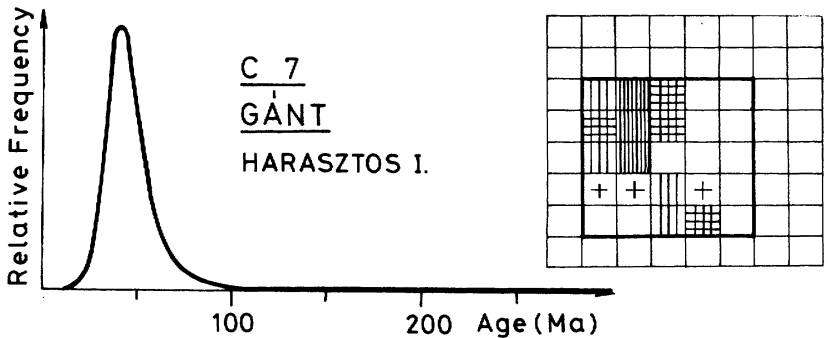

I. $A .=319$

1. $T .=442$

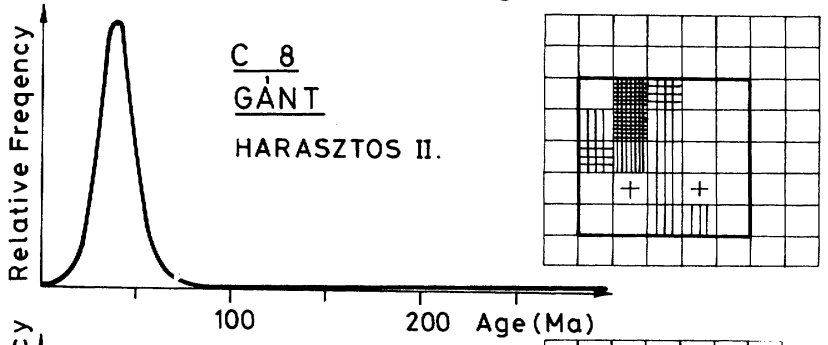

1.A. $=320$

1. $T .=430$

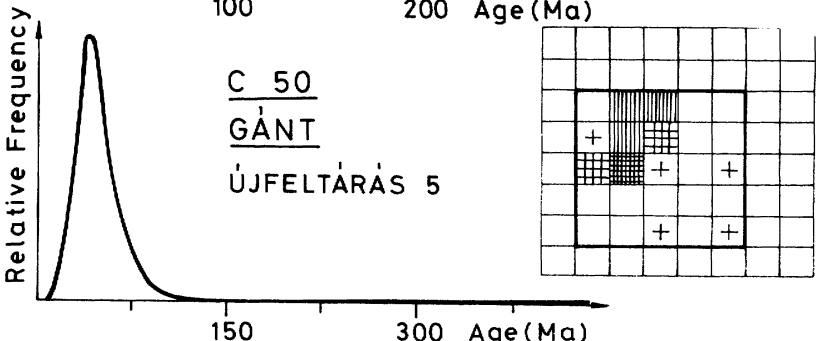

I. A. $=323$

1. $T .=419$

Fig. 7. Age spectra of zircon crystals from the studied bauxite samples (left), and the typologic classification (to the right). The crystal types represented by separate fields are shown by Fig. 6 . The pattern of the individual fields expresses the quantity of that particular type of crystal.

narrow range (something quite improbable when supposing the denudation of a uniform igneous sequence, as opposed to a contemporary single volcanic event), 


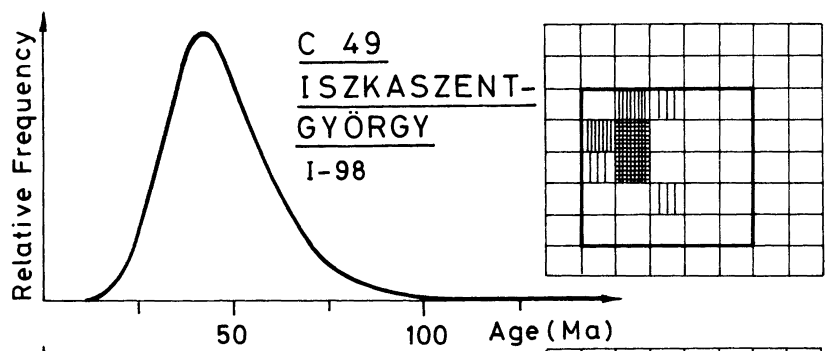

I. A. $=291$

1. T. $=427$

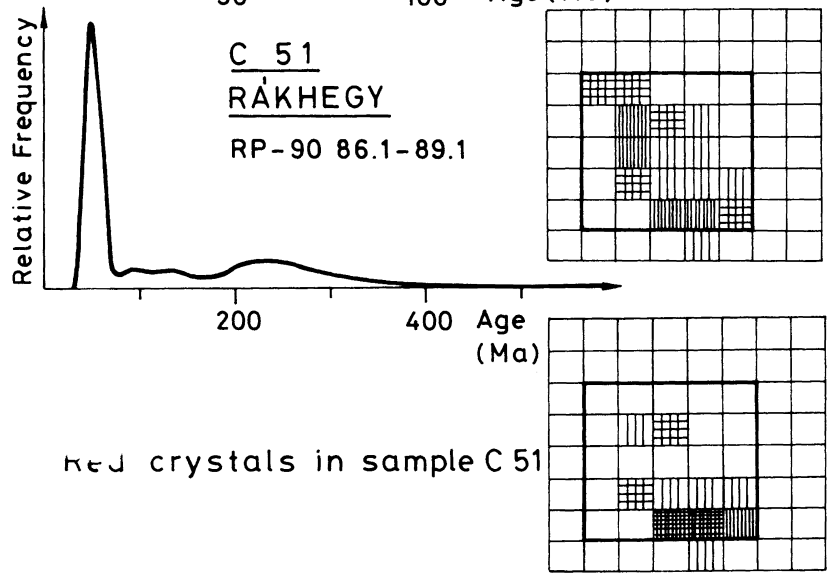

1. A. $=390$

1. $T .=536$

1. A. $=452$

I. $T .=638$

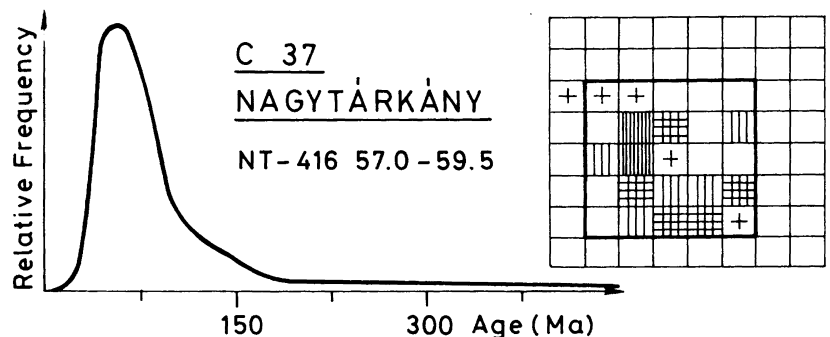

1. A. $=377$

1. $T=527$

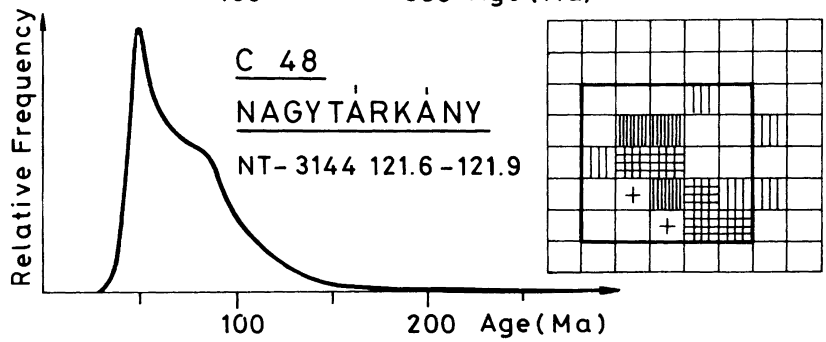

1. $A .=437$

1. T. $=533$

Fig. 7. (continued)

- the age of the younger zircon populations of the Eocene-covered samples is nearly the same in all the studied deposits even though they are geographically scattered over a distance of $180 \mathrm{~km}$,

- the younger group of the fission track ages coincides with or is only slightly older than the age of overlying Lutetian sequence.
B) The volcanic material could be of andesitic, or perhaps even rhyolitic composition.

- Mindszenty et al. (1988) determined traces of pyroclastics of calc-alkaline composition by means of microprobe.

- Zircons are rare or absent in basalts ; on the other hand it is true that the small number of 


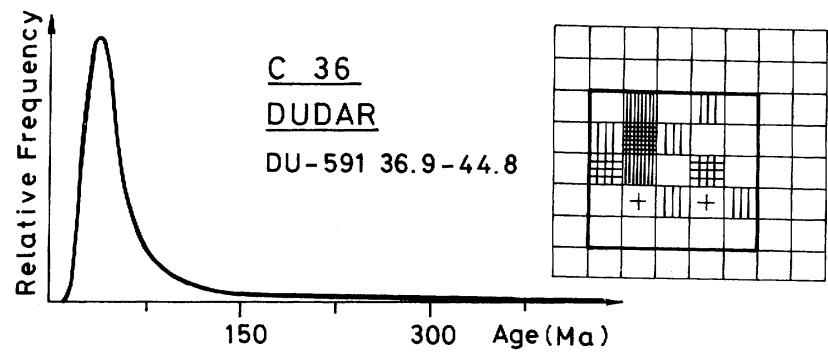

1. A. $=335$

I. T. $=435$

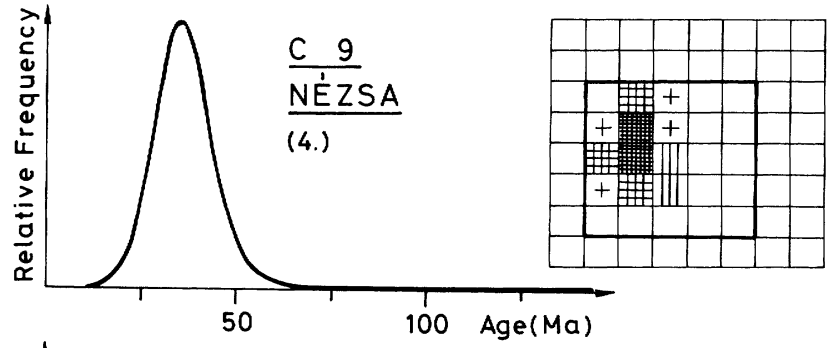

I. A. $=301$

1. $T .=455$

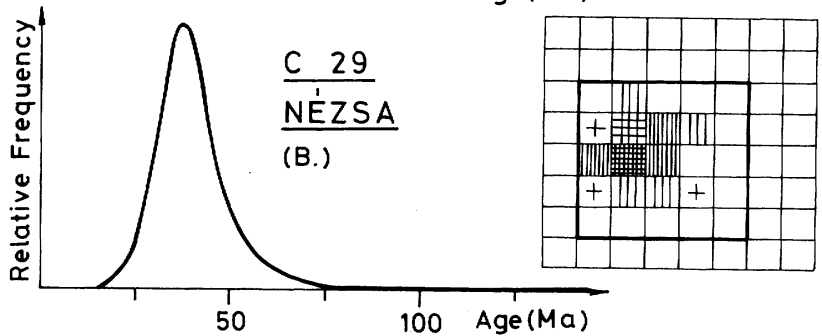

1.A. $=320$

1. $T .=478$

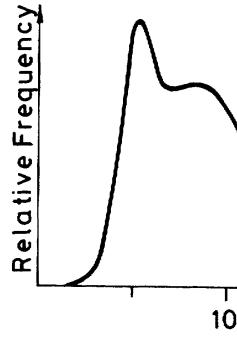

C 34

IHARKUंT

IK- $67 \quad 37.7-48.7$

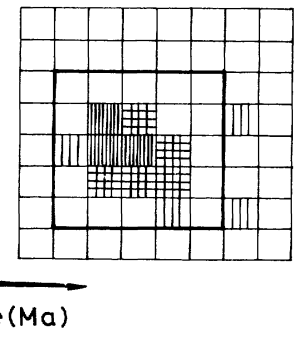

I. A. $=402$

I. T. $=509$

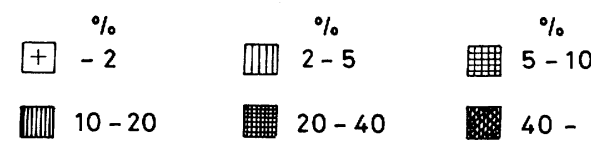

Fig. 7. (continued)

dihexagonal quartz grains mentioned from Hungarian bauxites does not seem to be sufficient to prove the rhyolitic composition either.

- This statement is supported very strongly by the morphometric results, too. The most widespread classes of S-7, S-12 when compared with the literature call for a tonalitic (or the equivalent effusive) igneous formation. The close relationship between the results of typologic analyses on zircon crystals of Paleogene volcanics of an- desitic composition of the Transdanubian Central Range and of zircons in the bauxites with Eocene cover, is unambiguous (Fig. 8).

It looks to be proved that the earliest traces of the subduction-related Upper Cretaceous - Oligocene calc-alkaline volcanism have been preserved in the bauxite deposits as the alteration products of subaerial ash falls. The Eocene climate and the karstic environnement provided favourable conditions to bauxite formation from 
a.)

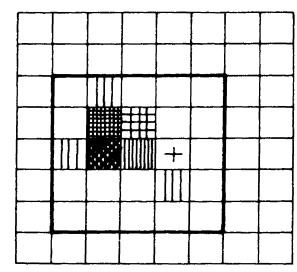

I.A. $=327$

I. $T .=468$ b.)

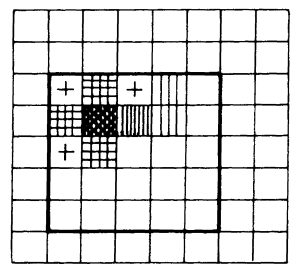

1. A. $=313$

I. $T .=401$

Fig. 8. The typologic centre of zircons collected at two different Eocene andesitic volcanic localities of Hungary, falling into fields S-7 and S-12.

a). Kápolnásnyék, Kny-3 borehole, $1140.2 \mathrm{~m}$, hornblende-andesite.

b). Recsk, R-357 borehole, $356 \mathrm{~m}$, metasomatised andesite.

this material. The weathering process could have been quite rapid (bauxites generated in less than one million years are also reported from lateritic terrains, Patterson, 1971).

It is worthy of mention, that in the lowermiddle part of the Middle Eocene marine sequence no traces of airborne or surface-transported volcanic mineral assemblages could be identified (Sárközy-Farkas, 1967 ; Radócz-Komáromy, 1971). Volcanism proper begins later on in the Late Lutetian only (Dunkl, 1990), which strongly suggests that there was a brief break between the burial of bauxite deposits preserving the traces of the early volcanic event and the onset of the large-scale volcanic activity. The abundance of ilmenite and zircon in the Eocenecovered bauxite deposits is probably interrelated ;

a.)

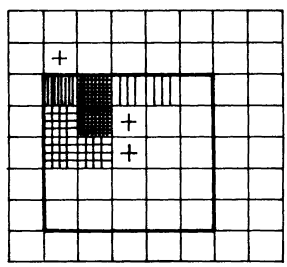

b.)

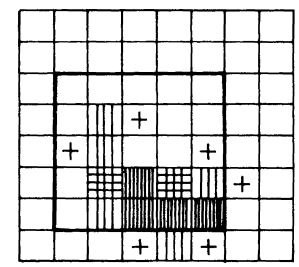

Fig. 9. Typologic diagrams of zircon crystals from bauxite drilled at Rákhegy Rp-102 borehole.

a). Colorless to light yellow crystals (FT age of the group : $48 \pm 6 \mathrm{Ma})$.

b). Red crystals (FT age of the group : $240 \pm 37 \mathrm{Ma}$ ).

the major part of the ilmenite grains arrived together with the zircons as constituents of the volcanic ash.

C) Concerning the older zircon populations showing ages between 200 and 260 million years it can be stated that :

- old crystals occur in only some of the deposits. Their greatest amount is found in the samples of Rákhegy. For example, in the bauxite sampled from $129.7 \mathrm{~m}$ depth in the Rp-102 borehole, all the zircon crystals are idiomorphic, but according to their color two groups can be distinguished of the same size. The two groups are of different typology and show different fission track ages as well. The colorless to light yellow population belongs to the Eocene volcanic group described under B) with typologic fields of S-7, $\mathrm{S}-12$. The red " old " crystals are characterized by typologic positions of S-23-24-25 (Fig. 9).

- The range of fission track dates from idiomorphic crystals producing old ages is the same as the FT ages of zircons of the Middle Triassic

a.)

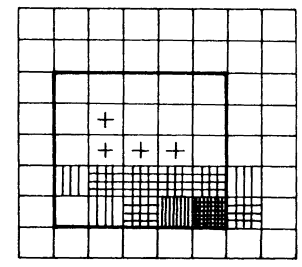

I. A. $=517$

I. $T=659$ b.)

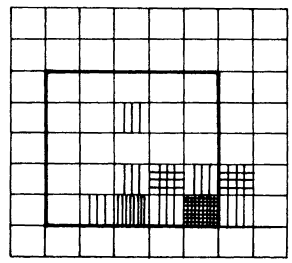

1. A. $=535$

I. $T .=655$ c.)

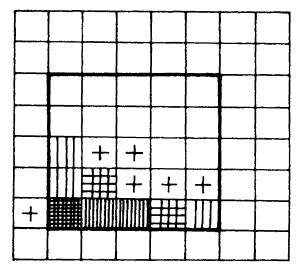

1. $A=308$

1. T. $=672$

Fig. 10. Zircon typologic diagrams of some Middle Triassic trachitic volcanics.

a). Budaörs, Kálvária Hill, green ignibrite pebble.

b). Felsöörs, Malom Valley, 1st tuff layer.

c). Felsöörs, Malom Valley, 2nd tuff layer. 
tuffs of the Bakony Mountains (Dunkl, 1990). This probably supports the theory of Szabó \& Ravasz (1970), i.e. in the course of erosion of the Southern Bakony Mountains, the Ladinian " pietra verde " formation served as a source rock for the bauxites.

- The idea of the Ladinian tuffs being potential source-rocks is proved also by the zircon morphology. The trachyandesitic composition of the Middle Triassic volcanites (Szabó \& Ravasz, 1970 ; Ravasz, 1973) and the typologic main point in the S-23-24-25 fields of the old zircon crystals are in good agreement since, according to Pupin (1980), crystals of this type of morphology also occur in trachyandesites. The typologic " center » of zircons separated from some Triassic volcanics of the Transdanubian Central Range falls into the field S-25 (Fig. 10a, 10b). Nevertheless, the problem is complex, i.e. one of the tuff layers of the Felsöörs Triassic profile is characterized by a distinct zircon population of S-21 position but no zircon crystals of this morphological character were ever found in our bauxite samples (Fig. 10c).

- I have to admit that in this case morphometry cannot be regarded as a truly decisive argument since similar zircon grains are found also in granitoids of anatectic origin. In the Bressanone area of the Southern Alps anatectic Hercynian granitoids are known that lie south of the Periadriatic lineament (Del Moro \& Visoná, 1982). As to the theory of Kázmér \& Kovács (1985), the Paleocene - Middle Eocene position of the Bakony Unit is close to the Bressanone granitoids. The derivation of the detrital matter from the south agrees well with the south to north detrital transport direction determined for the bauxite deposits occurring along the southern part of the Transdanubian Central Range (Antal, 1973 ; T-Gecse, 1982 ; Mindszenty, 1984). These facts are at least not in contradiction with the supposed sources at the southern side of the Balaton Line.

- In the course of the typologic analyses no grains relating to the Velence Granite were found. In the Velence Granite the zircon grains are of distinctly different morphology : their typologic position is P-4-5 characteristic of the alkaline sequences (Gbelsky \& Határ, 1982 ; my own results), see Fig. 11. This probably means that the Velence Granite was not yet exposed to erosion in the Lower Lutetian.

- The highly rounded old crystals closely relate to parametamorphics of Variscan cooling

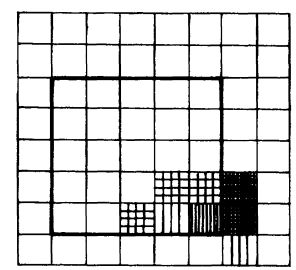

Fig. 11. Zircon typologic diagram of a typical granite sample from Velence Hills (Tác-1 borehole, $344.3 \mathrm{~m}$ ).

ages found in the SE and NW flanks of the Transdanubian Central Range synform and containing zircons of similar age and morphology.

D) Based on age and morphology, the large number of euhedral zircon crystals found in the Nézsa samples is identical to the young zircon crystals of the Transdanubian bauxites ; these are of volcanic origin. Their FT age younger than in Transdanubia relates to the later burial of the Nézsa deposit, i.e. in the Upper Eocene, and to the admixture of volcanic material which probably continued also in the Lower Oligocene, as well. Pyroclastics fallen into a marine environment formed tuffite layers intercalated in the Upper Eocene of Transdanubia whereas at Nézsa the tuffaceous material became bauxitized under terrestrial conditions and became inundated only later on by the sea. (It is in harmony with that the age of cover beds of Nézsa deposit is probably younger than the Transdanubian deposits. According to Vadász (1946) it could be Oligocene, Embey-Isztin (1971) mentioned a Middle Eocene Miliolina limestone while on the basis of the stratigraphic charts of Szantner et al. (1986) the immediate cover is a Priabonian coal sequence.)

\section{Conclusions}

- Preceeding the Lutetian transgression the exposed karst terrain of the Bakony Mountains received ash falls from the first explosions of the Paleogene calc-alcaline volcanism. The pyroclastic material underwent short transportation and contributed to the bauxite formation (these results proved the assumption of Gedeon, 1952).

- The volcanic material was of andesitic, probably of rhyolitic composition.

- The period of bauxite formation lasted up till the end of the terrestrial period, i.e. to the Lower Lutetian.

- In the case of some deposits, the Middle 
Triasic trachyte tuff found in the underlying sequence served also as source rock.

- It is possible that the weathering products of certain South Alpine anatectic granitoids also contributed to the bauxite formation.

- The characteristic zircon crystals of the Velence granite do not occur in the bauxites studied.

- Old and rounded zircon crystals relating to Variscan parametamorphics were also identified (though in smaller numbers) in the bauxite samples studied.

Acknowledgements : The bauxite samples were provided by J. Kiss (Eötvös University, Budapest) and by F. Szantner, K. Tóth and I. Horváth (Bauxite Exploration Co.). The Nézsa samples were collected with the help of $\mathrm{M}$. Kázmér. Zircon age standards were made by C.W. Naeser (Denver). Irradiations were made by G. Keömley and late J. Bérczi (Technical University, Budapest). An earlier version of this manuscript was reviewed by A. Mindszenty (Eötvös Univ.) and M. Tucker (Univ. of Durham). Thanks for their valuable aid.

\section{Appendix}

The zircon crystals were picked up by needle from the heavy mineral concentrates, then embedded in FEP-teflon. The spontaneous fission tracks were etched with the eutectic melt of $\mathrm{NaOH}-\mathrm{KOH}-\mathrm{LiOH}$ at somewhat lower temperature $\left(190^{\circ} \mathrm{C}\right)$ than suggested by Zaun \& Wagner (1985). Etching was carried out for different durations in each preparate ( 27 to 73 hours); the duration was determined by the optimal etching state of fission tracks and by means of the widening of polishing cracks. Neutron irradiation was made at the Technical University of Budapest. The external detector method was used (Gleadow, 1981), after irradiation the induced fission tracks in the mica detectors were etched by $40 \% \mathrm{HF}$ for 40 to $60 \mathrm{~min}$. Spontaneous track counts were made in oil immersion under a Zeiss NU 2 microscope, with magnification of 1600 ; in case of mica detectors dry optics of 800-time magnification were used. Only crystals embedded parallel to the c-axis, polished down to 20 microns at least and free of dislocations and near-surface inclusions were considered.

The age was calculated on the basis of the weighted average of the measured track density proportions, by the zeta-method (Hurford \& Green, 1983). Limits or error are given by using the classical procedure, i.e. by the double Poisson dispersion (Green, 1981).

This paper is a contribution to the IGCP Project 287/ Tethyan Bauxites.

\section{References}

Antal, S. (1973) : Micromineralogical and textural features in relation to the genesis of bauxite of Iszkaszentgyörgy. Acta Min. Petr., Szeged, 21, 316.

Báldi-Beke, M. (1974) : Nannoplankton from a bauxite lens at Tükrösmajor II. Csabrendek, Bakony Mts, W-Hungary. Földt. Közl., 104, 446-457 (in Hungarian with English abstract).

- (1984) : The nannoplankton of the Transdanubian Paleogene formations. Geologica Hungarica, Ser. Paleont., 43, 307 p.

Balla, Z. (1988) : The megatectonic picture of the Carpatho-Pannonian region in the Upper Eocene and the effect of this picture to the Mesozoic Tethys reconstructions. Földt. Közl., 118, 11-26 (in Hungarian with English abstract).

Barnabás, K. (1966) : The bauxite. in « Geology of the Hungarian mineral deposits », B. Jantsky, Müszaki Kiadó, Budapest, 143-178 (in Hungarian).

Bárdossy, Gy. (1961) : Sur la composition et la genése des bauxites de la Hongrie. Ann. Inst. Geol. Publ. Hung., 49/4, 1017-1028.

- (1977) : Karst bauxites. Akadémiai Kiadó, Budapest, 413 p. (in Hungarian).

Bárdossy, Gy. \& Pantó, Gy. (1973) : Trace mineral and element isvestigation in bauxites by electron-probe. Proc. ICSOBA 3. Congress, Nice, 47-53.

Bárdossy, Gy., Pantó, Gy., Várhegyi, Gy. (1976) : Rare metals of Hungarian bauxites and conditions of their utilization. Travaux ICSOBA, Zagreb, 13, 221-231.

Bignot, G., Blondeau, A., Guernet, C., Perreau, M., Poignant, A., Renard, M., Riveline, J., Gruas, C., Dudich, E., Kázmér, M., Kopek, G. (1985) : Age and characteristics of the Eocene transgression at Gánt (Vértes Mts, Transdanubia, Hungary). Acta Geol. Hung., 28, 29-48.

Boldizsár, T. (1948) : The origin of bauxite and other mineral gels from disperse systems. Bány. Koh. Lapok, 81, 231-237 (in Hungarian with English abstract).

Brokés, F. (1976) : Sedimentological studies in connection with the problematic microfossils found in the bauxites of Nagytárkány-Tüskesmajor II bauxite body, Myirád bauxite area, Bakony Mountains, Transdanubia, Hungary. Ann. Rep. of the Hungar- 
ian Geol. Inst., 415-445 (in Hungarian with English abstract).

Deák, M. (1960) : Palynologische Untersuchung der Bauxitlagerstätten im Bakonygebirge. Földt. Közl., 90, 125-131 (in Hungarian with German abstract).

- (1967) : Étude palynologique des bauxites à débris de plantes du mont "Bagoly ». Földt. Közl., 97, 224-226 (in Hungarian with French abstract).

Del Moro, A. \& Visoná, D. (1982) : The epiplutonic Hercynian complex of Bressanone (Brixen, Eastern Alps, Italy) - Petrographic and radiometric data. $N$. Jb. Miner. Abh., 145, 66-85.

De Weisse, J.G. (1948) : Les bauxites de l'Europe centrale. Mém. Soc. Vaud. Sci. Nat., Lausanne, 9/58.

Dudich, E. (1981) : Regional effects on the development of theories on bauxite genesis. Acta. Geol. Hung., 24, 247-255.

Dudich, E. \& Komlóssy, Gy. (1969) : Considérations paléogéographiques et tectoniques sur le problème de l'âge des bauxites en Hongrie. Földt. Közl., 99, 155-165 (in Hungarian with French abstract).

Dunkl, I. (1990) : The fission track method and application in solving geochronoligical questions. Ph. D. Theses, Hung. Acad. Sci., Budapest, 177 p. (in Hungarian).

- (1990) : Fission track dating of tuffaceous Eocene formations of the North Bakony Mountains (Transdanubia, Hungary). Acta Geol. Hung., 33, 13-30.

Embey-Isztin, A. (1971) : Contribution to the mineralogy of the bauxites from Nézsa (North-Hungary). Ann. Hist-Nat. Mus. Nat. Hung., 63, 5-12.

Földvári, A. (1933) : Der voreozäne Karst des transdanubischen Mittelgebirges. Földt. Közl., 63, 49-56 (in Hungarian with German abstract).

Fülöp, J. \& Dank, V. et al. (1978) : Geological map of Hungary without the Cenozoic, $1: 500000$. Geol. Inst., Budapest.

Gbelsky, J. \& Határ, J. (1982) : Zircon from some granitoid rocks of the Velence and Mecsek Mountains (Hungary). Geologicky Zbornik, 33, 343-363.

Gedeon, T. (1952) : The possibility of bauxite formation. Acta Geol. Acad. Sci. Hung., 1, 65-77.

Gleadow, A.J.W. (1981) : Fission-track dating methods : what are the real alternatives? Nuclear Tracks, 5, 3-14.

Góczán, F. (1973) : Comparative palynology and the paleoclimate of bauxite formation. Öslénytani Viták, 21, 51-63.

Green, P.F. (1981) : A new look at statistics in fission track dating. Nuclear Tracks, 5, 77-86.

György, A. (1923) : Bauxite deposit at Halimba (Veszprém county, Hungary). Bány. Koh. Lapok, 56, 5777 (in Hungarian).

Hidasi, J. (1986) : Role of carbonate rocks in the genesis of bauxite. Ann. Univ. Eötvös, Budapest, Sect. Geol., 26, 179-188.

Hurford, A.J., Fitch, F.J., Clarke, A. (1984) : Resolu- tion of the age structure of the detrital zircon populations of two Lower Cretaceux sandstones from the Weald of England by fission track dating. Geol. Mag., 121, 269-277.

Hurford, A.J. \& Green, P.F. (1983) : The zeta age calibration of fission-track dating. Chem. Geol. Isot. Geosci., 41, 285-312.

Jaskó, S. (1953) : Report on the result of investigations of Nagyegyháza bauxite deposit in years 1952-53. Manuscript, Bauxite Exploration Co., Balatonalmádi (in Hungarian).

Kázmér, M. (1984) : Continental escape of the Bakony-Drauzug unit in the Paleogene. Alt. Földt. Szle., 20, 53-101 (in Hungarian with English abstract).

Kázmér, M. \& Kovács, S. (1985) : Permian-Paleogene paleogeography along the Eastern part of the Insubric-Periadriatic lineament system : Evidence for continental escape of the Bakony-Drauzug Unit. Acta Geol. Hung., 28, 71-84.

Kiss, J. (1952) : La constitution minéralogique de la bauxite de Mézsa. Acta. Geol. Acad. Sci. Hung., 1, 113-132.

- (1953) : Vestiges fossiles dans la bauxite de Gánt. Földt. Közl., 83, 68-69 (in Hungarian with French abstract).

- (1955) : Recherches sur les bauxites de la Hongrie. Acta Geol. Acad. Sci. Hung., 3, 45-88.

Kiss, J. \& Vörös, I. (1965) : La bauxite lignitifère du mont Bagolyhegy (Gánt) et le mécanisme de la sédimentation de la bauxite. Ann. Univ. Eötvös, Budapest, Sect. Geol., 8, 67-90.

Komlóssy, Gy. (1967) : Contribution à la connaissance de la genèse des bauxites hongroises. Acta Geol. Acad. Sci. Hung., 11, 477-489.

- (1970) : The Iszkaszentgyörgy bauxite (SE Bakony Mts, Hungary) : Problems of genesis and mineral formation. Ann. Inst. Geol. Hung., 54/3, 347-358.

Mindszenty, A. (1970) : Tentative physico-chemical interpretation of the genesis and alteration of ilmenite in bauxites. Földt. Közl., 100, 382-387 (in Hungarian with English abstract).

- (1984) : The lithology of some Hungarian bauxites. A contribution to the palaeogeographic reconstruction. Acta Geol. Hung., 27, 441-455.

Mindszenty, A., D’Argenio, B., Bognár, L. (1986/87) : Cretaceous bauxites of Austria and Hungary : Lithology and paleotectonic implications. Travaux ICSOBA, Zagreb, 16-17, 13-31.

Mindszenty, A. \& Gál-Solymos, K. (1988) : Geological significance of the extraclasts of the Halimba bauxite-deposit. Ann. Rep. of the Hungarian Geol. Inst., 451-467 (in Hungarian with English abstract).

Mindszenty, A., Szintai, M., Tóth, K., Szantner, F., Nagy, T., Gellai, M., Baross, G. (1988) : Sedimentology and depositional environment of the Csab- 
puszta bauxite (Paleocene/Eocene) in the South Bakony Mts (Hungary). Acta Geol. Hung., 31, 339370.

Nemecz, E. \& Varjú, Gy. (1967) : Relationship between " flintclay " and bauxite formation. Acta Geol. Acad. Sci. Hung., 11, 453-473.

Oravecz, J. (1965) : Uber die erdgeschichtliche Rolle silurischer Gesteinschotter in den klastischen Schichtkomplexen Ungarns. Földt. Kölzl., 95, 401405 (in Hungarian with German abstract).

Pantó, Gy. (1980) : Geochemistry of rare earth elements and some fields of application. Theses for Doct. Sci., Budapest.

Patterson, S.H. (1971) : Investigations of ferruginous bauxite and other mineral resources on Kauai and a reconnaissance of ferruginous bauxite deposits on Maui, Hawaii. U.S. Geol. Survey, Prof. Paper, Washington, 656, $74 \mathrm{p}$.

Pávai-Vajna, F. (1948) : The origin of bauxite. Bány. Koh. Lapok, 81, 194-195 (in Hungarian with English abstract).

Pupin, J.P. (1976) : Signification des caractères morphologiques du zircon commum des roches en pétrologie. Base de la méthode typologique, applications. Thèse Doct. ès Sc. Univ. Nice (France), 394 p.

- (1980) : Zircon and granite petrology. Contrib. Mineral. Petrol., 73, 207-220.

Radócz-Komáromy, E. (1971) : Micromineralogical investigations of Eocene rocks in the Northern Bakony Mountain. Ann. Rep. of the Hungarian Geol. Inst., 133-139 (in Hungarian with English abstract).

Rákosi, L. (1977) : Age determination by pollens of bauxite deposits and redeposited dolomite breccias near Nagyegyháza. Ann. Rep. of the Hungarian Geol. Inst., 283-293 (in Hungarian with Russian abstract).

Ravasz, Cs (1973) : Mineralogical-petrographical studies on Middle Triassic tuffs of the Transdanubian Central Mountains, Hungary. Acta Min. Petr., Szeged, 21, 123-139.

Sárközi-Farkas, E. (1967) : Sedimentpetrographische Untersuchung der Eozäns in der Umgebung von Tokod. Ann. Rep. of the Hungarian Geol. Inst., 237-246 (in Hugarian with German abstract).

Szabó, E. (1976) : Genetical problems of the karts bauxite deposits in Transdanubia, Hungary. Alt.
Földt. Szle., 9, 21-66 (in Hungarian with English abstract).

Szabó, I. \& Ravasz, Cs. (1970) : Investigation of the Middle Triassic volcanics of the Transdanubian Central Mountains, Hungary. Ann. Hist. Nat. Mus. Nat. Hung., 62, 31-51.

Szantner, F., Knauer, J., Mindszenty, A. (1986) : Bauxite prognosis. Veszprém. 463 p. (in Hungarian).

Szantner, F. \& Szabó, E. (1970) : The structural-geological conditions and history of development of Hungarian bauxite deposits. Ann. Inst. Geol. Hung., 54/3, 109-129.

T-Gecse, É. (1982) : Micromineralogical study of the Nagyegyháza bauxite deposit. Ann. Rep. of the Hungarian Geol. Inst., 435-448 (in Hungarian with English abstract).

Telegdi-Roth, K. (1927) : Die bauxitlager des Transdanubischen Mittelgebirges in Ungarn. Földtani Szemle, Budapest, 1, 33-45.

Vadász, E. (1946) : Die geologischen Entwicklung und das Alter der ungarnischen Bauxitvorkommen. Ann. Inst. Geol. Publ. Hung., 37/2, 235-286.

- (1951) : Bauxite geology. Akadémiai Kiadó, Budapest, 127 p. (in Hungarian).

- (1956) : Bauxite et terra rossa. Földt. Kölzl., 86, 115-119 (in Hungarian with French abstract).

Vendel, M., Kisházi, P., Boldizsár, I. (1971) : Genesis of bauxite deposits of Transdanubian Central Range. Bány. Kut. Int. Közl., 15, 7-43 (in Hungarian with English abstract).

Vörös, I. (1958) : Examen microminéralogiques et des éléments sporadiques des coupes de bauxite de Iszkaszentgyörgy. Földt. Közl., 88, 48-56 (in Hungarian with French abstract).

Vörös, I. \& Gecse, É. (1976) : Micromineralogical and sedimentological study of some Hungarian bauxites. Travaux ICSOBA, Zagreb, 13, 175-183.

Zaun, P.E. \& Wagner, G.A. (1985) : Fission-track stability in zircon under geological conditions. $\mathrm{Nu}$ clear Tracks, 10, 303-307.

Received 8 August 1991

Accepted 11 December 1991 
Downloaded from https://pubs.geoscienceworld.org/eurjmin/article-pdf/4002362/581_gseurjmin_4_3_581_596_dunkl.pdf
by Montanuniversitaet Bibliothek user 